ECONOMIC THEMES (2019) 57(1): 51-65

DOI 10.2478/ethemes-2019-0004

\title{
CLUSTERS AS AN EXPRESSIVE FORM \\ OF BUSINESS INFRASTRUCTURE (ANNEX THEORY ANALYSIS)
}

\author{
Ivana Kostadinović \\ University of Niš, Faculty of Economics, Republic of Serbia \\ $\triangle$ ivana.kostadinovic@eknfak.ni.ac.rs \\ UDC \\ 334.758 \\ Review \\ paper

\begin{abstract}
In modern conditions of development, the connection of small and medium enterprises into clusters is an increasingly important and current trend. Constant changes taking place on the global market, the growth of competition and the changes in the business of many companies, encourage them to connect into clusters and, in this way, to compete with large enterprises. In that way, small and medium-sized enterprises retain their market position, as well as legal and business independence and achieve significantly better results. Enterprises, also grouped into clusters, have a comparative advantage, which is based on cooperation, greater flexibility and their specialization. In addition, connecting into clusters also leads to an increased competitiveness of enterprises, due to the introduction of innovations, the development of new technologies, the increase of productivity, the acceptance of new quality standards. The aim of the paper is to point out the importance of the theoretical aspect of clusters as an important element of business infrastructure and to emphasize that the development of clusters is essential for the development of small and medium enterprises, considering the fact that they enable them to become more productive and innovative, as well as more competitive compared to the period when they operated independently and separately.
\end{abstract}

Received:

03.01.2019

Accepted:

28.02.2019
Keywords: clusters, small and medium enterprises, organizational structure, state, competitive advantage.

JEL classification: L22

\section{Introduction}

Clusters are one of the most important elements of business infrastructure. The need for clusters' development has been recognized by the European Union (EU) institutions, which was supported by numerous project initiatives in the Republic of 
Serbia, in many ways. "The experience of EU countries suggests that the competitiveness of the entire economy can be significantly increased by linking enterprises to clusters, especially in traditional and mature industrial branches, with the state having an important role in developing systems and institutions to support their development" (Bošković \& Kostadinović, 2011, p. 67). Clustered businesses realize synergistic effects that result from sharing their own experiences, knowledge, information and improving interactional connections.

When it comes to clusters' development, the experience of the Republic of Serbia is more than modest. Although there are few clusters in Serbia, they have been developed without any clear rules, organization, vision and mission. Perhaps one of the reasons why this is the case is precisely the misunderstanding of the clusters' concept, as well as its role and importance for the development of the region.

Clusters are of the crucial importance for the development of the region - they influence the increase in their competitive advantages on the global market. Bearing in mind all these facts, it is necessary to involve the state in the clusters' development itself, in terms of creating an institutional framework, a favorable business environment for a smooth and successful development of clusters, stimulating and encouraging the connection of enterprises.

Small and medium-sized enterprises (SMEs) are very often unable to enter the market because they are not able to meet all the requirements of that market. It is necessary, for this reason, to associate enterprises in clusters and, in this way, to perform more safely on the market and to increase the added value of their product, which is common in this case.

The concept of clusters is accepted in many countries, as a driver of innovation and economic development, as well as a significant solution for the survival and growth of SMEs (Porter, 1990). Clusters in contemporary conditions are one of the possible responses to the process of globalisation and uneven regional growth and development. The existence of clusters, as well as their development, represents the most efficient way to raise the economy of the region to a higher level.

Clusters, as a relatively new method and a model of the development of SMEs are intensively developing in countries with a longer tradition and countries that have experience in developing a small business, qualified and educated workforce and developed institutions.

\section{Approach to definining clusters}

Clusters are the key to the development of each country, both highly industrially developed and developing countries. They also represent a very significant form of organization, which has a great impact on production potential, competition and competitive export advantages and opportunities in all economies. 
In economic literature, clusters have been mentioned since 1990, when Michael Porter published his famous work "The Competitive Advantages of Nations" (Porter, 1990). Many other well-known theorists were also writing about clusters, but his contribution was the greatest. Porter emphasizes the importance of clusters for increasing the competitive position of companies on both domestic and international market, which defines them as the "geographical concentration of interconnected companies, specialized suppliers, service providers, related businesses and relevant institutions (for example, universities, agencies for standardization, tourism and trade associations), which in some areas compete with each other, but also cooperate "(Mićić, 2010, p. 59).

The word cluster is originally English - it comes from the word "cluster" (bundle, set, flock, sword, bunch, bouquet, group) first used by an American composer to mark a set of tight, simultaneously densely-strung tones (Cappellin \& Wink, 2009).

Clusters are very important as they enable enterprises to become more productive and innovative, as well as more competitive, compared to the period when they operated independently and separately. The term cluster is sometimes replaced by the term Porter's cluster, which is quite understandable, considering the fact that Michael Porter was the first one to use and popularize clusters. Since then, they have become the subject of interests for experts and theorists worldwide. Clusters are also increasingly mentioned as an unavoidable element in the analysis of national economies - the concepts of clusters are used for different business structures such as: regional cluster, national cluster, industrial cluster, production cluster, innovative cluster, cluster of knowledge, etc.

In the last few years, clusters have become one of the key concepts in many new development initiatives, strategies and policies in Europe, as well as in other countries of the world (Dragićević \& Obadić, 2006). The essence of this concept is the cooperation, as a joint action of at least two companies, in order to increase the overall business performance, which is always greater than the collection of individual effects. Enterprises on the market are not isolated entities, but they interact with clients, suppliers, competition and other public institutions in their activities, and the very system of relationships that the company establishes with other entities can significantly affect its competitive advantage (Bošković \& Kostadinović, 2011).

Strong competitive advantages in the global economy can mainly be found in the local things - knowledge, relationships, motivation - the differences that competitors cannot easily copy, which can be best and easily developed through clustering. In this sense, the "cluster definition itself emphasizes the significance of the local environment, members' interconnection and geographical constraints, in spite of the growing processes of globalization and the ever-growing development of the so-called virtual economy" (Bošković \& Kostadinović, 2011, p. 59). 
The cluster, which develops in a particular location, depends on the business environment. Michael Porter introduced the "diamond" in 1990 as an analytical tool for explaining the business environment, i.e. the environment. Generally speaking, the diamond includes four elements: (1) production factors (physical infrastructure, skills, etc.), (2) demand conditions (sophistication of local consumers, production and consumer regulation), (3) strategy and competitiveness and (4) the presence of appropriate, supportive industries. These elements are interconnected and influence both companies and clusters. They show the effects of the system, in which the weakest element almost always has the strongest impact on the overall quality. Diamond can also be used to analyze the quality of the business environment at the regional and national levels (Kostadinović \& PetrovićRanđelović, 2013).

The adequate clusters' definition depends on the activities and segments in which companies operate, the functions they perform, and the strategies they use. „Clusters can appear in different industries, sectors, subsectors, areas, groups and industry groups, or at the level of small local firms (restaurants, shops or agricultural producers). They can be formed in large and small economies, developed and undeveloped countries, in urban and rural areas, at several geographical levels (in the country, between regions within the country or between regions, between neighboring countries, in wider urban areas, in cities). Some clusters consist primarily of SMEs, while others include large and small firms, universities, higher education and research institutions" (Mićić, 2010 p. 59, 60).

Various definitions are given by literature explaining in very constructive ways what clusters are and what they are dealing with. "Definitions depend on the context of observation and purpose. From an economic point of view, the main goal is a better understanding of competition and growth, while other definitions focus on different objectives, such as providing legal bases for funding or a reference model for statistical measurement "(European Commission, Europe INNOVA, PRO INNO Europe, 2008, p. 9). Therefore, when it comes to the concept of clusters, it should be pointed out that in developing countries the concept is still not precisely and clearly defined, as well as in our country.

a) „One of Porter's short definitions is that clusters are a critical mass of businesses and institutions in one place, of an unusual competitive success in certain fields“" (Bošković \& Kostadinović, 2011, p. 59).

b) According to Porter, a cluster is a group of interconnected companies and related institutions located in the vicinity, engaged in a particular activity, and associated with common characteristics and complementarity (Porter, 2008).

c) "Clusters represent a specific form of networking for enterprises and other supportive organizations that are spreading numerous economic and non-economic benefits and strengthening social capital within the communities in which they develop" (Dragičević \& Obadić 2013, p. 15). 
d) Clusters are commonly defined as ,groups of related and spatially close companies, organizations and institutions that recognise the common interest and are mutually supportive, encouraging creative energy to systematically improve processes in the production, placement and product innovation chain, in order to acquire and maintain a competitive advantage" (Gligorijević \& Bošković, 2007, p. 109).

e) Cluster association is a "relatively new form of organizational connection of economic entities in the function of increasing efficiency and competitiveness" (Stanisavljević, 2014, p. 237).

f) Clusters represent a magnet to attract foreign investors, as well as foreign investment and the driving force of export growth (Porter, 2008).

g) State Aid Administration for Research, Development and Innovation defines clusters as "a group of independent enterprises - an innovative approach, small, medium and large enterprises, as well as research organizations operating in a specific sector and region, designed to stimulate innovative activities, through the promotion of intensive interaction, object exchange, knowledge sharing and expertise and effectively contribute to technology transfer, networking and dissemination of information among enterprises in the cluster (European Commission, Europe INNOVA, PRO INNO Europe, 2008).

h) An industrial cluster is a set of industrial enterprises in the region that cooperate, horizontally and vertically connected. Industrial clusters make firm connections between buyers and sellers, as well as economic institutions that support their development. Given the fact that the industrial cluster consists mainly of export-oriented firms, it brings a new wealth to the region and contributes to its economic development (Stimson et al., 2006).

i) In a broader sense, clusters can be defined as a group of companies close to each other with mutual economic goals and institutions, having reached the required level for the development of expertise, services, resources, suppliers and skills. A common element of most cluster definitions is the fact that they represent a concentration of one or more areas within one region, as well as networking and collaboration between companies and institutions (European Commission, Europe INNOVA, PRO INNO Europe, 2008).

j) Clusters as "... a set of economic activities of economic entities, institutions, geographically concentrated (locally or regionally) that have established formal or informal relationships between themselves, horizontal and vertical, and the affinity of the industrial sector through which they exchange information, knowledge and goods for the production of a common product" (Horvat \& Kovačević, 2004, p. 15).

k) In the process of functioning, the cluster is mostly manifested as a union and a set of business entities and other institutions that are not imposed on the connection. "The cluster develops the specifics of the company and allows the company to choose the level and type of cooperation in the cluster, as well as to 
define the part of the business activity that enters the cluster, and with whose part it functions independently" (Maksimović \& Mićić, 2014, p. 152).

1) "Enterprises linked to clusters achieve synergistic effects resulting from the improvement of interaction links and the exchange of information, knowledge and experience" (Laketa \& Laketa, 2013, p. 201).

m) Clusters are an important driver of innovation and competitiveness of the entire economy, especially export companies. Conquering new markets and supporting export activities will help cluster companies to use the processes of European integration and globalization of the market (Serbian Chamber of Commerce, 2016).

\section{The process of forming and functioning of clusters}

Clusters' formation represents a very complex and long-lasting socio-economic process. Clusters are not something that can be quickly and simply created and produced. Clustering needs time; it usually takes several years to form a successful cluster. First of all, it is necessary to create a good strategy for their development and, occasionally, to make certain changes. "Otherwise, the process of cluster formation itself involves different phases, of which the following four are the most important: (1) identifying the potential for clustering; (2) market research; (3) assessment of suppliers' adequacy and (4) identification of economic basis of industry" (Gligorijević \& Kostadinović, 2012, p. 8).

In addition to the above mentioned phases, it is necessary to emphasize the main goals that occur during the formation of clusters (Ciriković, 2013): (1) development of the cluster network, (2) training and education of personnel, (3) strengthening cooperation among the intermediate subjects, (4) continuous growth and development of the cluster, (5) the establishment of dialogue and cooperation with government and scientific institutions, (6) linking with potential funding providers for innovative projects whose realization requires significant financial resources, (7) strengthening the identity of clusters and its members, (8) interconnection of clusters in the national and international economy, and other.

Stewart Rosenfeld in his 2002 Guide to Governance in Climate Economics, said: "Those who decide on business policies should remember that clusters are cultivated, and not created. The most successful clusters in the world have not developed through a lucky set of circumstances, but by placing strong foundations. Public policy can be a catalyst for growth, but most often quite accidental and rarely with the intention of launching a cluster. The growth of the largest clusters was driven by market demand and entrepreneurial spirit" (Andreozzi, 2005, p. 11).

Cluster formation itself takes place in several steps and phases (Jovetić \& Ilić, 2005). The first step involves defining industrial branches of so-called old 
branches, which have the greatest impact on economic growth and development. Then, in the second step, the positioning of these branches of future clusters in the market, domestic and international, is done. The third step requires an old firm to be determined, and in the last, the fourth step, an adequate choice of strategy for networking is carried out.

By connecting enterprises to clusters, an opportunity is created for increasing their competitiveness, easier access to new markets, and easier access to financial sources (loans, funds). Cluster financing may be the most important factor of sustainability and their further development. The very form of cluster survival faces restrictions on access to favorable sources of financing both in the money market and the capital market. In addition, the restrictions also apply to financial institutions that will monitor cluster development, lack of qualified and experienced staff, insufficient readiness for team work, as well as development of long-term business partnerships, as a long-term cooperation. The most sophisticated forms of ownership and market linkage of clusters are currently applied only in developed countries of the world.

The cluster functions by emphasizing and developing all the specifics of the cluster member, allowing it to choose the type and level of cooperation in the cluster, considering the fact that this connection is in not imposed, nor are the companies forced into such a type of cooperation. Cluster members make estimations based on location (land, climatic conditions), availability of raw materials, proximity of scientific and research institutions, as well as important market, specialized workforce, depending on the fact whether this type of cooperation corresponds to them and whether they thus achieve greater benefits compared to the one when they operate independently on the market, both domestic and international.

There are several common elements in the way clusters work, and they must be organized in the best possible way (Ciriković, 2013):

a) Basic business - the most important thing in a cluster, through which the cluster is most accomplished and through which it has the greatest benefits.

b) Support business - operations that directly or indirectly help the realization of basic operations.

c) Intellectual support infrastructure - in clusters that function in basic and supportive business, they do not work separately, isolated. In such clusters many members of the local community participate and they, in addition, support cluster activities as key actors in them.

d) Physical support infrastructure - the elements of physical infrastructure, whose quality, at least, must be at the same level or even better than the competition, consisting of: roads, ports, warehouses, landfills, communication networks, etc. 
For the successful functioning of the cluster, the following factors are important (Gligorijević \& Kostadinović, 2012): the basis of company performance in accordance with their production, market access and innovation; focus on benefits as a basis for the active participation of partners in the cluster; readiness to actively exchange knowledge which, above all, refers to the so-called "tactic knowledge"; construction, as well as the development of mutual trust; active participation of all partners in network management, coordination of cluster activities and internal and external linking (cluster management); organized joint public and market performances (PR cluster and distribution system).

\section{Organizational structure of the cluster}

Each country has different ways of organizing enterprises into clusters. Most clusters in the EU have been created on the basis of a simple agreement on joint work and cooperation, as well as research on all possibilities for a long-term cooperation between cluster members during the first years of existence. In addition to the above mentioned agreement, i.e. the agreement between the companies that refers to the cluster, their initial operation in the market, other ways of organizing the cluster are more important. With the development of clusters and market operations, better and more secure appearance in foreign markets, they are transformed towards the formation of a business association or consortium.

The success of the cluster, as well as their organizational structure, depends on the choice of potential partners. The fact is that the choice of a partner is one of the harder jobs and sometimes it takes a long period of time to find partners. When partners are finally found, the next very important step is to define the rights and obligations of partners. It is also important to establish rules of cooperation, define expectations and requirements, and make precise decisions on future development of a cluster, being a very important element of business infrastructure.

The organizational structure of clusters is of crucial importance for their functioning. Only if it is well-placed, simple, flexible, efficient, transparent and operational, clusters can increase the benefits of their businesses. "Similarly, the organizational structure must be integrative and open enough to involve a large number of different competing partners and participants, while at the same time sufficiently exclusive and selective to ensure stable cooperative structures and the quality of the cluster" (Scheer \& Zallinger, 2008, p. 41). It must be set up in the way that the cluster can confront and adapt to changes in the competitive market. The organizational structure has a great influence on the competitiveness of clusters, taking into account that only those with simple and efficient organizational structures can have a successful and safe performance both on the domestic and international markets. 
A well-established organization determines competencies within the cluster itself. In this way, it is easier to perform tasks, and more easily exchange information and data between different departments and enterprises, as parts of the cluster.

In any case, it is recommended that the statute determines the organizational structure of the cluster, to be signed by all companies, which will be a binding basis for cooperation in the cluster.

The organizational structure should be simple and thus enable better and more efficient collaboration within the cluster, as well as to encourage clusters to be more oriented towards the companies that make it. Therefore, if the clusters meet all the specific requirements of their companies, that is, if they enable them to increase their productivity, profit and efficiency, as well as to achieve a competitive advantage on the market, their attractiveness will be higher.

The cluster organizational structure plays a very important role in creating a cluster brand in the market. The same varies depending on the cluster target. If the cluster goal is to jointly carry out business activities, a different organizational structure is needed in relation to clusters whose goal is, for example, joint research and development.

Speaking of the organizational structure of clusters, it is necessary, first of all, to emphasize their partners with characteristics: (1) Vertical chain - one large enterprise; (2) Horizontal chain - industries that use common channels of procurement and sales, or produce complementary products and provide services; (3) Institutions - non-productive institutions that provide cluster organizations with specific skills, technology, information, capital or infrastructure; (4) The state - a very important actor of a cluster organization (Andreozzi, 2010).

\section{The role of the state in cluster development}

The future of cluster development and the survival would be quite uncertain without the support of the state. Namely, the state has a significant role in the process of clustering, and its support in the form of laws that stimulate the development of clusters, tax incentives, incentive funds and the like is extremely important. It encourages the development of clusters through the creation of a favorable business and institutional environment and for the purpose of balanced regional development. The state and its institutions have an activist approach, which is necessary due to the significant influence of clusters on the competitiveness of the industry and creating a favorable environment that favors clusters, encouraging their founding and future development.

The state should enable the conditions and a suitable climate for the development of clusters, through infrastructure, laws and institutions, as well as creating a favorable environment for the arrival of foreign investors. "Due to the 
importance of the development of regional and national economies, the countries and governments of the states are helping the development of clusters, from establishing connections and dialogue among enterprises, through measures of fiscal and monetary policy, to financing clusters in a certain period of time" (Karavidić \& Ivković, 2010, p. 115).

SMEs connect to clusters in an attempt to compensate for all they lack, such as financial resources, professional personnel, new knowledge, modern technology, etc. However, the future of cluster survival would be quite uncertain if the state would not participate in the process of forming them. Without its immense support in the form of tax reliefs, incentives and laws (which encourage the development of clusters), the process of formation and further cluster development would be difficult in conditions of increasing competition on the market.

The state should substantially support the creation of the necessary conditions for the development of successful clusters. Here, first of all, is meant to create a stable macroeconomic environment; development of transport and market infrastructure; development of research and development institutions, professional consulting, knowledge base, system development and quality standardization institutions, loan insurance, etc. (Kostadinović \& Petrović-Ranđelović, 2013). The basic role of the state is reflected in: active creation of favorable business opportunities, legal and institutional framework; defining the cluster development strategy, as well as the impact on all factors that directly or indirectly influence their development. Developmental policies are important for the smooth functioning and development of the same.

The state strives to help and participate in the most efficient way, both in the emergence and in the further development of the cluster. The state, state institutions, as well as local authorities, also want to provide adequate support for the development of clusters, in order to achieve certain economic advantages that they bring to the region. Regions with developed clusters have a far better living standard of the population, as well as more stable economic development. For this reason, these authorities bring new measures to support the development of clusters in that area. Their usage depends on the situation in the environment, but also on the cooperation of cluster members, authorities and other factors in the region (in that area).

The state, agencies, associations, chambers of commerce and the nongovernmental sector have a very important role in the construction process, as well as in the business of clusters. This is because a lot of investments are needed for their formation, as well as functioning, which without the help of the state and other actors would not be feasible or successful. Therefore, we say that the state can, directly and indirectly, support cluster development, whereby direct assistance is reflected on improving the conditions of business itself, through systemic and institutional changes, while indirect government assistance refers to the creation of an economic policy that stimulates the development of clusters (Mićić, 2010). 
"Construction of the industrial cluster is a progressive process, which requires a continuous improvement of knowledge. In addition, in overcoming the difficulties encountered in this process, the state, as well as the leading economic factors involved in cluster creation and business, should play an important role" (Gligorijević \& Kostadinović, 2012, p. 10).

State support can be in the form of laws, tax or other incentives, but the support is also reflected through the formation of expert teams for assistance and monitoring of cluster business and organizing training of cluster employees (Krstić, 2011).

Connecting enterprises into clusters and clusters' development itself may have one of the most important roles in achieving economic development and increasing the competitiveness and innovation of developing countries on their path to the EU. That is why it is necessary to provide maximum support and protection to enterprises which are grouped in clusters, and provide them with legal regulations, institutional framework and financial resources for smooth functioning, in the first place.

The state can use appropriate innovative service models (more prominent is the One-Stop-Shops model), partnerships and many incentive and advanced programs to encourage and accelerate the development of clusters, but it cannot literally "build" them. For smooth functioning of the cluster, it is also necessary to support the state administration, without which everything would be much more difficult and with more restrictions.

The role of the state is not to try to build clusters because clusters are spontaneously organized and appearing, but help to strengthen already existing clusters, in various ways. "The first step in this process would be: (1) research in order to determine the degree of development of a single cluster; the following steps are: (2) determining needs and (3) creating the measures needed to improve cluster performance. In this sense, engaging the public sector can be extremely creative, especially when it comes to overcoming certain weaknesses of existing clusters" (Bošković \& Jovanović, 2009, p. 115).

\section{Conclusion}

Clustering of enterprises and the development of clusters can play a significant role in achieving economic development, as well as improving the competitiveness of developing countries. The most important advantages of connecting companies to clusters are: the increase in production volumes, the increase of exports, strengthening of human capacities, the improvement of product quality, the reduction of costs, a higher level of specialization, greater flexibility, more favorable environment for innovative activities, development and cooperation, easier problem solving. Companies face smaller business failures when making some important decisions, due to a better exchange of information. Taking into account the advantages listed above, companies that are cluster's members can 
achieve more impressive results than companies that act independently and separatly on the market and they are not ready for any kind of cooperation and mutual assistance.

Clusters positively influence the overall business operations of the company, as well as their position on the market (domestic or international), since there is an increase in the productivity and efficiency of member firms. The fact is that businesses connect in clusters in order to improve their current market position and increase stability, as well as to create common benefits.

The organizational structure, which should be operational and flexible, is of the utmost importance for the normal and efficient functioning of the cluster, so that they can successfully perform on the domestic and international market, and in order to make the companies, which are cluster's members, have the greatest benefits. The organizational structure of the cluster is also important due to constant changes on the market, because only the well-formed structure can be monitored in order to properly react. It is recommended that clusters have a simpler organizational structure, which also represents the basis for cooperation, in order to enable as efficient and better cooperation within the cluster.

The success of the cluster, as well as their organizational structure, depends on the choice of potential partners. The fact is that the choice of a partner is one of the harder decisions to make and sometimes it takes a long period of time to find the right partners. Once they are found, the next very important step is to define the rights and obligations of partners. It is also important to establish the rules of cooperation, define expectations and requirements, and make precise decisions on future development cluster as a very important element of business infrastructure.

Joining companies into clusters leads to an increase in their competitiveness, due to the adoption of innovations, the development of new technologies, and the latest quality standards and increasing labor productivity. Since the development of clusters in Serbia is still at an early stage, as well as the level of competitiveness of enterprises, the role of the state is significant because without its support, the future of cluster development would be quite uncertain. An active role of the state is also important in terms of stimulating association, legal regulations, creating a favorable business environment, as well as creating an institutional framework for successful cluster development.

The role of the state should also be reflected in the improvement of the effectiveness of antitrust policy, the continuation of the initiated economic reforms, the creation of a favorable institutional environment for attracting strategic foreign investors, as well as foreign direct investment, which are of utmost importance for a single country. In addition, by creating a favorable environment, the state stimulates cluster association with universities, institutes, and other important scientific institutions, all with the aim of more efficient and faster development of clusters, as well as industry and economy as a whole. 


\section{References}

Andreozzi, B., (2005). Priručnik o razvoju klastera, Projekat promocije zapošljavanja, Ministarstvo za rad, zapošljavanje i socijlnu politiku Republike Srbije, Beograd.

Andreozzi, B., (2010). Razvoj klastera, Beograd: Ministarstvo rada, zapošljavanja i socijalne politike.

Bošković, G., Jovanović, A. (2009). Uticaj klastera na konkurentnost i regionalni razvoj industrije, Ekonomske teme 47 (1), (pp. 107-119).

Bošković, G., Kostadinović, I., (2011). Klasteri malih i srednjih preduzeća - ključ ekonomskog razvoja, Škola biznisa, (4), (pp. 54-68).

Cappellin, R., Wink, R. (2009). International Knowledge and Innovation Networks-Knowledge Creation and Innovation in Medium-technology Cluster, USA: Edward Elgar.

Ciriković, E., (2013). Klaster organizacija kao faktor konkurentnosti malih i srednjih preduzeća, Tranzicija, 15(31), (pp. 87-95).

Dragičević, M., Obadić, A., (2006). Regionalni klasteri i novo zapošljavanje u Hrvatskoj, EFZG working paper series, (03), (pp. 1-27).

Dragičević, M., Obadić, A., (2013). Klasteri i politike razvoja klastera, Ekonomski fakultet Sveučilišta u Zagrebu, Zagreb.

European Commission, Europe INNOVA; PRO INNO Europe, (2008). The Concept of Clusters and Cluster Policies and Their Role for Competitiveness and Innovation: Main statistical results and Lessons Learned. Luxembourg: Office for Official Publications of the European Communities.

Gligorijević, Ž. \& Bošković, G. (2007). Mehanizam unapređenja konkurentnosti industrije, Ekonomski fakultet, Niš.

Gligorijević, Ž., Kostadinović, I., (2012). Industrijski klasteri: važna poluga mehanizma za unapređenje konkurentnosti industrije, Nauka+praksa br. 15, GAF, (pp. 5-13).

Horvat, Đ., Kovačević, V., (2004). Clusteri-put do konkurentnosti, Zagreb: CERA PROM d.o.o.

Jovetić, S., Ilić, M., (2005). Poslovni klasteri kao novi modeli uključivanja malog biznisa i evropske integracije, Ekonomske teme, 43(2), (pp. 223-232).

Karavidić, S., Ivković, D., (2010). Preduzetništvo, monografija, Visoka škola za poslovnu ekonomiju i preduzetništvo, Beograd.

Kostadinović, I., Petrović-Ranđelović, M., (2013). Industrijski klasteri kao razvojna šansa: iskustvo Srbije i zemalja u okruženju, Antikrizne politike i postkrizni procesi: izazovi ekonomske nauke, Ekonomski fakultet, Niš, (pp. 393-412).

Krstić, B., (2011), Konkurentske strategije i finansiranje razvoja malih i srednjih preduzeća, Bar: Fakultet za poslovni menadžment.

Laketa, M., Laketa, L. (2013). Klasteri kao model povezivanja malih i srednjih preduzeća u funkciji oživljavanja privrede Srbije, EMC Review - časopis za ekonomiju $i$ tržišne komunikacije/Economy and Market Communication Review, (ur. Darko Uremović), Panevropski univerzitet Apeiron, Banja Luka, BiH, 3(2), (pp. 200-215).

Maksimović, Lj., Mićić, V. (2014). Poslovni klasteri kao način za podsticanje ekonomske delatnosti - primeri u lokalnoj privredi grada Kragujevca, Stanje i perspektive ekonomskog razvoja grada Kragujevca, Ekonomski fakultet Univerziteta u Kragujevcu, Kragujevac, (pp. 151-161).

Mićić, V., (2010), Klasteri-faktor unapređenja konkurentnosti industrije Srbije, Ekonomski horizonti, 12(2), (pp. 57-74).

Porter, M. E., (1990). The competitive advantage of nation, London, Macmillan. 
Porter, M., (1990). The Competitive Advantage of Nations, New York, Free Press.

Porter, M., (1998). Clusters and the New Economics of Competition, New York, Harvard Business Review.

Porter, M., (2008), O konkurenciji, FEFA, Beograd.

Privredna komora Srbije, (2016). Strategija razvoja klastera u Srbiji 2015-2020., Centar za mala i srednja privredna društva, Beograd.

Scheer, G., Zallinger, L., (2008). Klaster menadžment - A priručnik, izrađen u okviru „Programa podsticaja razvoja klastera u Srbiji“", Ministarstva ekonomije i regionalnog razvoja Republike Srbije i Deutsche Gesellschaft für Technische Zusammenarbeit (GTZ) $\mathrm{GmbH}$, Beograd.

Stanisavljević, N. (2014). Klasteraska organizacija - konceptualne osnove i elementi životnog ciklusa, Ekonomika, 60(3), (pp. 237-246).

Stimson, R., Stough, R., Brian, R., (2006). Regional Economic Development - Analysis and Planning Strategy, New York.

Zdravković, M., (2006). Aglomeracije i tokovi međunarodne trgovine - doktorska disertacija, Beograd.

\section{KLASTERI KAO IZRAŽAJNI OBLIK POSLOVNE INFRASTRUKTURE (PRILOG TEORIJSKOJ ANALIZI)}

Apstrakt: U savremenim uslovima razvoja sve značajniji i aktuelniji je trend povezivanja malih i srednjih preduzeća u klastere. Konstantne promene koje se dešavaju na globalnom tržištu, rast konkurencije, kao i promene u poslovanju mnogih preduzeća, podstiču ista da se udružuju u klastere i da, na taj način, budu konkurenti velikim preduzećima. Tako, mala i srednja preduzeća uspevaju da zadrže svoju tržišnu poziciju, pravnu i poslovnu samostalnost i ostvaruju održivi rast i poslovanje. Preduzeća, takođe, grupisana u klastere, imaju komparativnu prednost, koja se zasniva na kooperaciji, većoj fleksibilnosti i njihovoj specijalizaciji. Pored toga, povezivanje u klastere dovodi i do povećanja konkurentnosti preduzeća, i to zahvaljujući uvođenju inovacija, razvoju nove tehnike i tehnologije, povećanju produktivnosti rada, prihvatanju novih standarda kvaliteta. Cilj rada je da ukaže na važnost teorijskog aspekta klastera kao važnog elementa poslovne infrastrukture, kao i na to da je razvoj klastera od suštinske važnosti za razvoj malih i srednjih preduzeća, imajući u vidu da im isti omogućavaju da postanu produktivnija i inovativnija, kao i konkurentnija, u odnosu na period kada su poslovala samostalno i odvojeno.

Ključne reči: klasteri, mala i srednja preduzeća, organizaciona struktura, država, konkurentska prednost. 


\section{Author's biography}

Ivana Kostadinović was born on 19.10.1982. in Munich. She graduated from the Faculty of Economics in Niš in 2007. She, defended her master thesis under the title "Economic analysis of the European model of regionalization of the Republic of Serbia". Doctoral academic studies at the Faculty of Economics in Nis, in the field of Macroeconomics, she has finished in 2016 and defended her doctoral dissertation titled "Business Infrastructure as a New Industrial Policy Instrument of the Republic of Serbia". Since 2008 she has been working at the Faculty of Economics in Niš, first as a teaching assistant, then as an assistant and since 2017 as an assistant professor in Economics of Industry, Industrial Management, Economics of Tourism and Regional Economics. She is the author of several scientific papers published in the leading national journals and proceedings of scientific conferences, of national and international significance. 